\title{
$7 \mathrm{MHz}$ 帯域 $\mathrm{AE}$ 波形シミュレーションとレーザ励起縦波 速度モニタリングによる遅れ破壊の ダイナミックスと前駆過程
}

竹本幹男*, 正木龍士*, 田中栄吉*

* 青山学院大学理工学部

\author{
Dynamics and Precursor of Delayed Fracture Studied by the Waveform \\ Simulation of $7 \mathrm{MHz}$ Acoustic Emission Signals and \\ by the Laser Excited Longitudinal Wave Velocity \\ Mikio Takemoto*, Ryuji Masaki* and Eikichi Tanaka* \\ * Faculty of Science and Engineering, Aoyama Gakuin University
}

\begin{abstract}
With the aim of studying the precursor and dynamics of delayed fracture of high tension steel, we developed two advanced elastic wave monitoring systems. One is a broad-band digital AE monitoring equipment consisting of a multi-resonant $7 \mathrm{MHz} \mathrm{AE}$ sensor, a $10 \mathrm{MHz}$ pre-amplifier and a $200 \mathrm{MHz} \mathrm{A} / \mathrm{D}$ converter. The overall transfer function was determined as a response to a pulse YAG laser break-down of silicon placed in slit (or crack). The break down was found to simulate the Mode-I fracture with effective source rise time of $0.035 \mu$ s and successfully utilized to determine the overall transfer function of the system. The waveform simulation of the monitored AE signals revealed the succession of fast and small $(<10 \mu \mathrm{m})$ cleavage cracks with source rise time of $0.07 \mu \mathrm{s}$ to $0.24 \mu \mathrm{s}$ in high hydrostatic stress field. In the $20 \mathrm{MHz}$ laser-ultrasonic system developed, a velocity change of spherical longitudinal (P-) wave was continuously monitored to detect the precursor of delayed fracture. Here, the P-wave was excited by pulse YAG laser so that it propagates through the hydrostatic stress field. The velocity decreased by $100 \mathrm{~m} / \mathrm{s}$ at $2.8 \mathrm{ks}$ before the first AE signal. The velocity decrease appears to be due to hydrogen induced voids. The method has potential for monitoring the precursor of delayed fracture.
\end{abstract}

Key words : waveform simulation, acoustic emission, transfer function, break-down, laser ultrasonic, delayed fracture

\section{1. 緒}

\section{言}

鋼の高強度化に対するニーズは高いが, 高強度化に伴 い感受性を高める遅れ破壊の発生・伝播のメカニズムに ついては未解明な点が多い. 遅れ破壊の前駆過程として は, 拡散性水素によるマイクロボイドの生成と合体, 格 子脆化，微小割れの発生・合体などが考えられている が，これらを証明する直接的情報を報告した研究は少な い. 前駆過程をリアルタイムにモニターする方法として アコースティック・エミッション (AE) や超音波が考 えられる。

$\mathrm{AE}$ の逆解析によって環境劣化割れの速度（キネティ ックス）を調べる研究1) 3) は 1980 年代にはじめられ, 現在では source characterization ${ }^{4), 5)} や$ moment tensor 解析 ${ }^{6), 7)}$ によって破壊のダイナミックス（割れの幾何学 的情報（キネマティックス）とキネティックス）を評価 することができる，著者らは，変位センサーを用いて実 体波面外変位を，また共振型センサーを用いて緹波放射 パターンを測定し，解析的応答関数（第 2 種グリーン関 数）を用いるダイナミックス推定法：source simula-

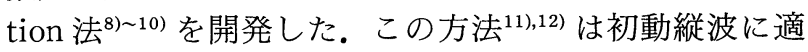

* $\bar{~}$ 157-8572 東京都世田谷区千歳台 6-16-1 (6-16-1, Chitosedai, Setagaya, Tokyo, 157-8572 Japan)
用できるが, 変位センサーの周波数帯域は約 $1 \mathrm{MHz}$ 程 度で, 遅れ破壊に応用した場合 $0.5 \mu \mathrm{s} よ り$ 遅い微小破 壊しか計測できないという問題があった ${ }^{13)}$. 遅れ破壊中 には $0.5 \mu \mathrm{s}$ 以下の高速破壊が発生することが予見され るが，このような高速破壊による実体波を検出するため には少なくとも $5 \mathrm{MHz}$ 帯域の $\mathrm{AE}$ 装置が必要である. 多重共振型 $\mathrm{AE}$ センサーを用いれば広帯域をカバーでき るが，センサーの応答特性が不明なため媒体と AE 装置 を一括した応答関数を実験的に求める必要がある。しか し, 広帯域応答関数を求めるための音源は提唱されてい ない.そこで，スリット（あるいはき裂）内に注入した 液体のパルスレーザ・ブレークダウンを利用してへき開 型破壊を模擬し, 一括応答関数を求める方法を開発し た. はじめに, ブレークダウンの物理現象とダイナミッ クスを明らかにし, 次に一括応答関数を用いた波形シミ ュレーションによって低合金鋼の遅れ破壊中の微小破壊 のダイナミックスを推定した。

一方, 提唱する方法によって高速微小破壊のダイナミ ックスは推定できるようになるが, 水素ボイド発生など の前駆過程についての情報は得られない.そこでレーザ 超音波装置を用いて, 高静水圧部を横切るように伝播さ せた $20 \mathrm{MHz}$ 帯域の縦波を連続的に検出し, 縦波速度 の時間変動からどのような組織や構造の変化が検出でき るかの基礎実験を行った。 


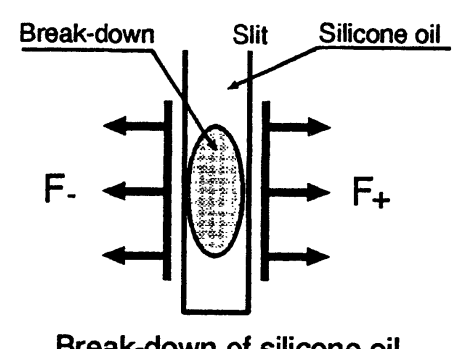

Break-down of silicone oil

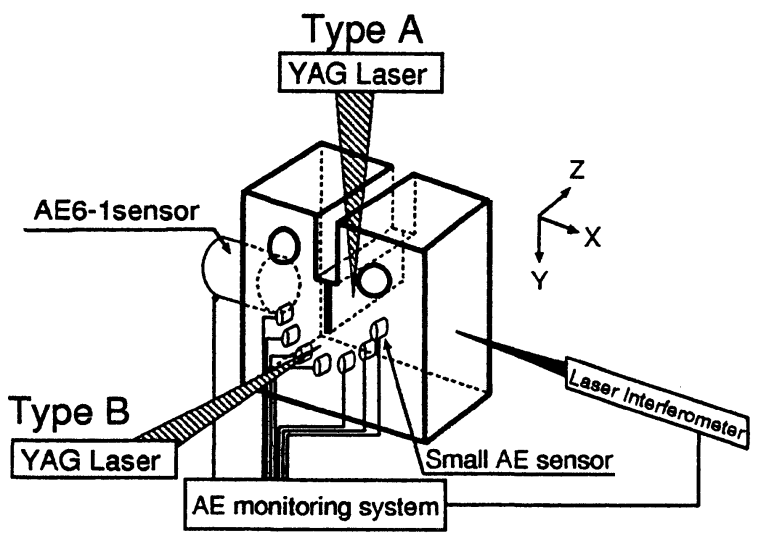

Fig. 1 Experimental setup for producing artificial Mode-I fracture by laser break-down of silicone oil in slit of $\mathrm{CT}$ specimen.

\section{2. 隙間内に充塡したシリコンオイルのブレーク ダウンによる人エへき開型破壊}

Fig. 1の上図に示したように，スリット（またはき 裂）内に注入した液体に点焦点パルス YAGレーザを照 射すると, 液体のブレークダウン（ガスまたはプラズマ 状態になって瞬間的に膨張）によってき裂壁に等しい大 きさの逆向きの力 $F$ (balanced force) を与え，へき開 型破壊（dipole source）を模擬できる。そこで, 焼入 れ・焼戻し $\left(850^{\circ} \mathrm{C} \times 3.6 \mathrm{ks}\right.$, oil quench 後 $550^{\circ} \mathrm{C} \times 2.4$ ks で焼戻し) SCM 440 の CT 試験片に, き裂を模擬し た $0.8 \mathrm{~mm}$ 幅のスリットを導入し，シリコンオイル (液体であれば水でもかまわないが今回は蒸発しにくい オイルを用いた）を注入し，半值持続時間 $5 \mathrm{~ns}$ のパル ス YAGレーザでブレークダウンさせた．試験片寸法は 後述する Fig. 5 に示したが, 負荷用のピン孔と電解槽 をもつ $24.5 \mathrm{~mm} \times 60 \mathrm{~mm} \times 60 \mathrm{~mm}$ の CT 試験片である.

Fig. 1 下図のように，レーザはスリット導入方向（図 の $Y$ 方向）から照射する方法（Type-A） と側面（ $Z$ 方向）から照射する方法（Type-B）を用いたが， Type-A は板幅中央のへき開破壊を, Type-Bではレー ザ焦点が表面から $1 \mathrm{~mm}$ になるように照射して側壁近 傍の破壊を模擬する。

ブレークダウンによる負荷方向の面外変位 $U_{x}(x, t)$ をへテロダイン型レーザ干渉計（BM インダストリー， $\mathrm{SH} 100$, 帯域 $20 \mathrm{MHz}$ ) で計測するとともに, 多重共 振型センサー14) (以後 $\mathrm{AE} 6-1$, 共振周波数の異なる PZT 素子を集合させて広帯域を持たせたセンサー）で $\mathrm{AE}$ を検出した。 また, 試験片側面の半径 $30 \mathrm{~mm}$ の円

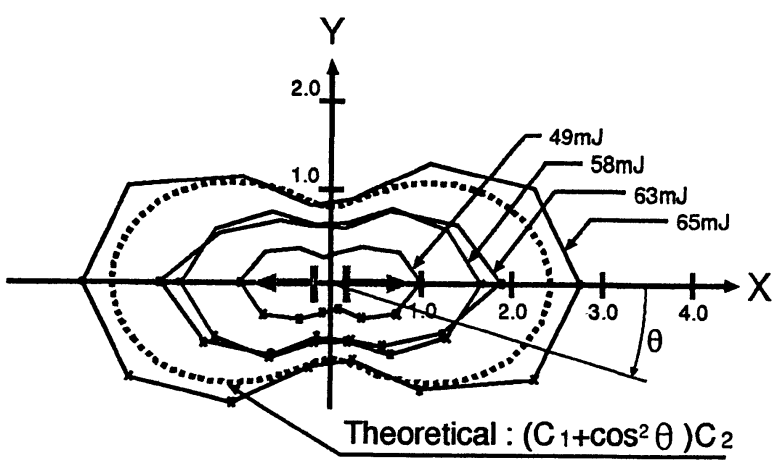

Fig. 2 Amplitude distribution of the P-waves produced by laser break-down of silicone oil in the slit.

周上に取りつけた 6 個の共振型小型 $\mathrm{AE}$ センー (PAC社, Type PICO) で縦波放射パターンを測定し た. 干渉計の出力は, 高速ディジタイザー A（テクト ロニクス RTD 720, サンプリング時間 $4 \mathrm{~ns}, 4098$ 点, 振幅分解能 8 bit）でディジタルデータとした。また, $\mathrm{AE}$ センサー出力は $10 \mathrm{MHz}$ プリアンプで $40 \mathrm{~dB}$ 増幅 後, ディジタイザーB（オートニクス APC 510, サン

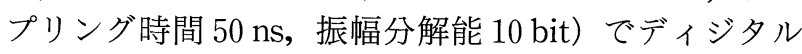
データにした後，ワークステーションで解析した。

レーザエネルギーは 26〜 $66 \mathrm{~mJ}$ まで変化させたが, Fig. 2 には, $49 \mathrm{~mJ}$ での最大振幅（バーガースベクトル 方向で $X$ 方向）を 1.0 としたときの Type-A スリット での縦波振幅分布を示す。レーザエネルギーが大きくな ると振幅は増加するが，その分布はへき開型破壊による 解析的振幅分布 ${ }^{6}$ ( 破線で示した分布で $C_{1}\left[C_{2}+\cos ^{2} \theta\right]$, $C_{1}$ と $C_{2}$ は定数) と良く一致しており，へき開型破壊が 模擬できている.Fig. 3(a)には干渉計による面外変位 を示す.インパルス初動縦波 $\left(\mathrm{P}_{1}\right)$ を正確に捕えてい る.この面外変位に対し, 媒体の第 2 種グリーン関数 $T_{x x}\left(x, t ; x, t^{\prime}\right)$ を用いた波形シミュレーションを行っ て音源の物理量を調べた。すなわち，(1)式によって縦 波面外変位 $U_{x}(x, \dot{t})$ を計算し, 検出緹波変位と一致す るようにき裂体積の時間変化 $A b_{x}\left(x^{\prime}, t^{\prime}\right)$ を求めた。

$$
U_{x}(x, t)=A b_{x}\left(x^{\prime}, t^{\prime}\right) * T_{x x}\left(x, t ; x^{\prime}, t^{\prime}\right)
$$

なお, 記号* は畳込み積分を意味し, $A$ はき裂面積, $b_{x}$ はき裂開口変位である. Fig. 3 の波 (b) は, (c) に示 した実効立ち上がり時間 $\Delta T r^{*}=0.035 \mu \mathrm{s}$ ，体積 $\Delta V=$ $8.5 \times 10^{-14} \mathrm{~m}^{3}$ のパルス状原波形に対して計算した面外 変位で，検出波(a)に見られる $5.3 \mu \mathrm{s}$ の $\mathrm{P}_{1}$-波, $9.4 \mu \mathrm{s}$ のS-波と一致している. なお, 原波形の初動立ち上が りは, $\sin ^{4}(\pi t / \Delta T r)$ ランプ関数で近似しているので, $0.1 \mu \mathrm{s}$ の立ち上がり時間 $\Delta T r$ に対する実効立ち上がり 時間 $\Delta T r^{*}$ （初動波振幅の $10 \%$ から $90 \%$ までの時間） は $0.035 \mu \mathrm{s}$ になる ${ }^{9)}$. 初動縦波部分を拡大して比較した ものを(d)に示す. 計算 $\mathrm{P}$ 波の初動は検出波と一致して いるが, 初動波ピークの $0.05 \mu \mathrm{s}$ 後には別のピークが観 察されている.この波は, スリット幅が小さかったた め, レーザがスリット壁にあたって断熱膨張を起こした ことによる波と考えられる，このため，(a)に見られる ように計算では見られないはずのいくつかのピークが観 察されている。この問題は, 短焦点レンズを用いてレー ザ径を絞れば解決できるし，また，実際の波形シミュレ 

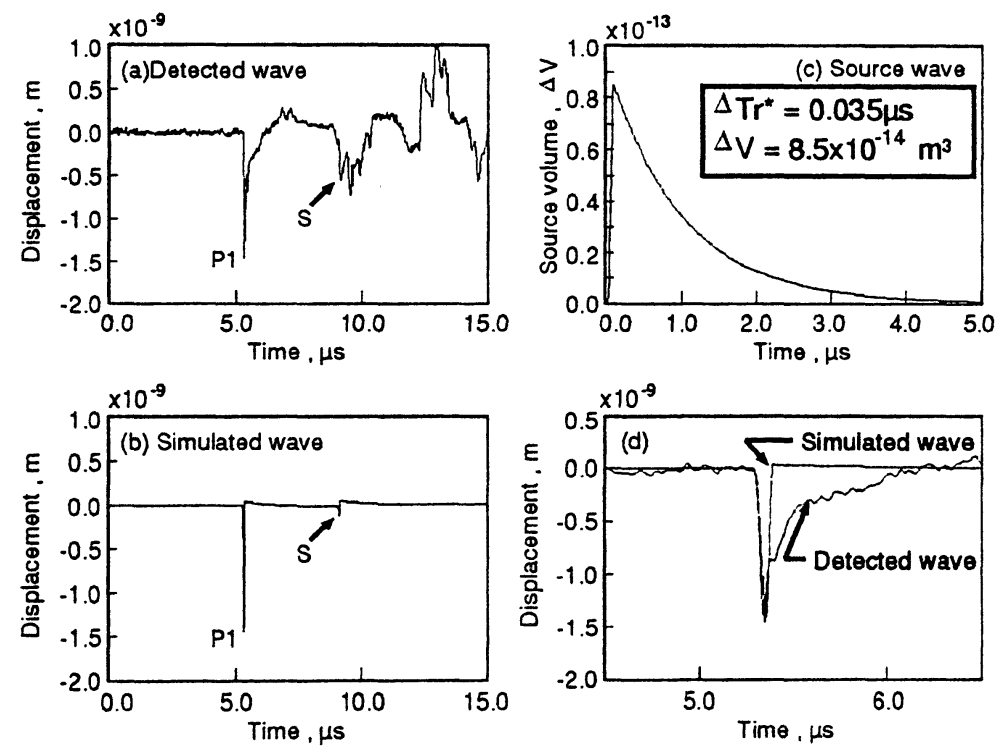

Fig. 3 Procedure for estimating the source wave(c) of break-down of silicone oil in the slit by the waveform simulation (b, d) to detected out-of-plane displacement (a).

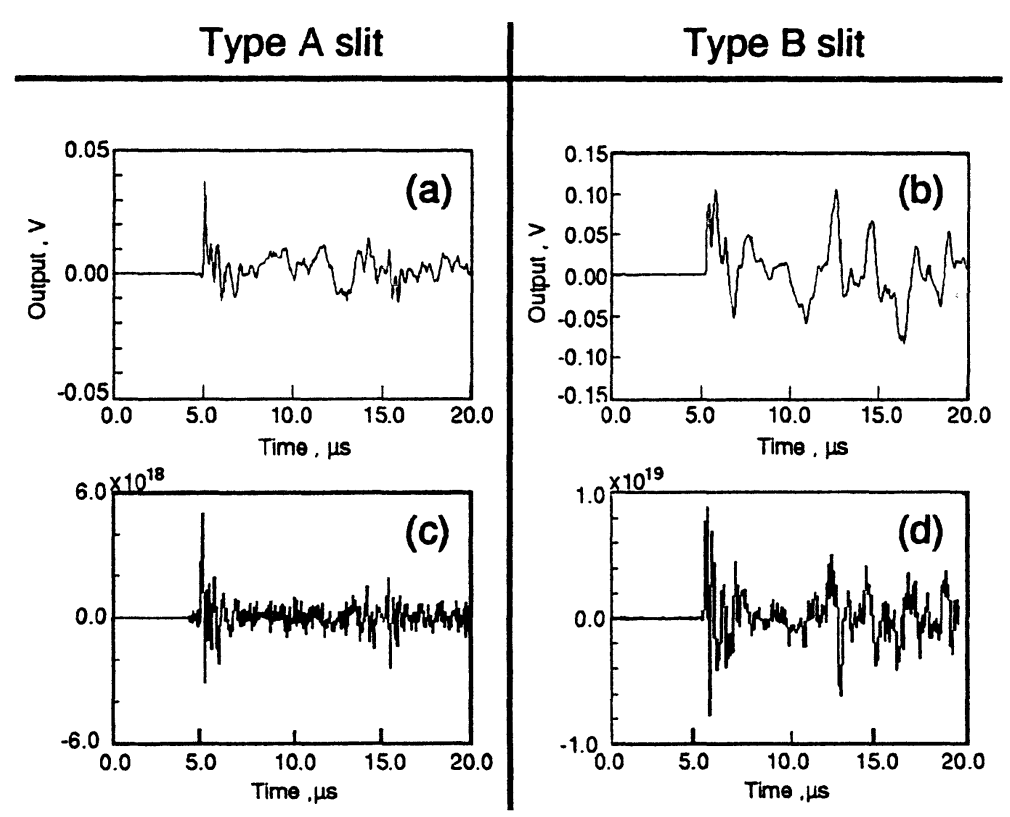

Fig. 4 Waveform (a,b) and over-all transfer function (c, d) obtained using the break-down of silicone oil in Type A and B slit.

ーションは初動縦波について行うので大きな問題にはな らない.ブレークダウンの原波形は，これまで提唱され ている最も早い人工音源，たとえば $0.5 \mathrm{~mm}$ のの゙ラス キャピラリーの圧壊 $\left.{ }^{15}\right)(\Delta T r=0.54 \mu \mathrm{s})$ では再現でき ない高速破壊を模擬できる。Type-A，-Bスリットに対 するレーザエネルギーと立ち上がり時間 $\Delta T r^{*}$ の関係 を調べたが, $\Delta T r^{*}$ はレーザエネルギーには無関係で $0.035 \mu \mathrm{s}$ と一定であった。一方, 体積はレーザエネル ギーとともに直線的に増加した。

ブレークダウンの面積 $A$ を調べるため，金を真空蒸 着したスリット内でブレークダウンを行い破損膜の形状 を調べた。その結果，破損膜の幅はほぼ $0.38 \mathrm{~mm}$ で，
長さは $1.1 \mathrm{~mm}$ であった. 面積は $4.2 \times 10^{-7} \mathrm{~m}^{2}$ となる ので,き裂体積 $8.5 \times 10^{-14} \mathrm{~m}^{3}$ から逆算される $b_{x}$ は約 $0.2 \mu \mathrm{m}$ となる。なお，レーザエネルギーを変化させて も面積の変化は極めてわずかであった，すなわち，同じ レーザ装置を使うかぎり $A$ は一定となるので, 模擬き 裂の体積は開口変位量 $b_{x}$ に比例することになる， $b_{x}$ は 材料の衝撃応答に対応するので，材料の弾性特性に影響 される。

次に, 媒体と $\mathrm{AE}$ 計測装置 (AE 6-1 センサーとプリ アンプ）を一括した応答関数を求めた. Fig. 4 の (a), (b) は，それぞれ Type-A と-B スリット内のブレーク ダウンによる $\mathrm{AE}$ 波で, 干渉計の出力 (Fig. 3(a)) と 


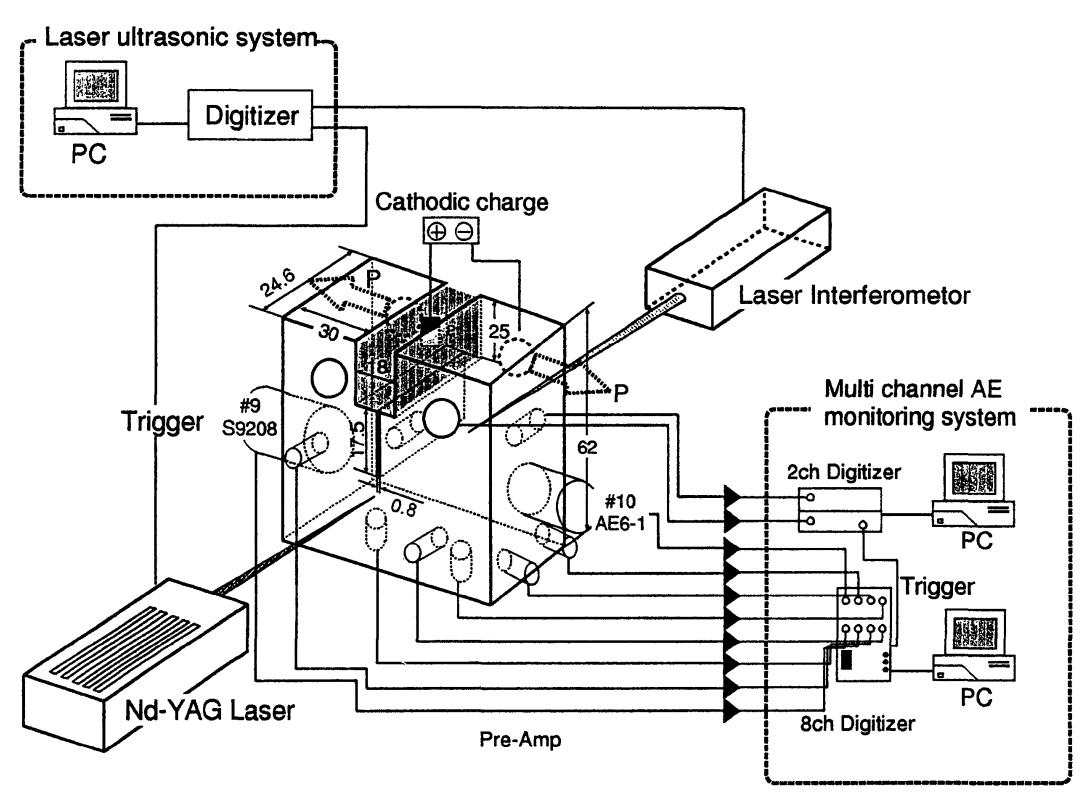

Fig. 5 Experimental setup for monitoring $7 \mathrm{MHz} \mathrm{AE}$ and laser-excited P-wave velocity.

比べると，センサーの応答関数のためポラリティーが逆 になっているほか，波形もかなり複雑になっている。ま た，Type-B スリットでは試験片側壁からの反射波が入 ってくるため, Type-A に比べて波形は複雑になってい る.これらの波をブレークダウンの原波形 (Fig. $3(\mathrm{c})$ ) で逆畺込み積分して一括応答関数 (c) と (d)を得 た。応答関数は，時間領域でも周波数領域の逆盢込み積 分でも求まり，媒体と $\mathrm{AE}$ センサーの応答特性を反映し たものになっており，7 MHz 帯域を有している。なお， 応答関数は音源位置によって変わるため, 遅れ破壊実験 を中断した開口き裂内にレーザを照射して逐一求める必 要がある.

\section{3.コンパクトテンション型試験片の遅れ破壊の ダイナミックス}

\section{1 実験 装 置}

試験法を Fig. 5 に示す.ノッチ部には電解チャージ で水素を供給するため, 幅 $10 \mathrm{~mm}$, 深さ $25 \mathrm{~mm}$ の電解 槽を設け，その先に幅 $0.8 \mathrm{~mm}$, 深さ $17.5 \mathrm{~mm}$ のスリ ットを導入した。試験片両サイドには，0.5 mm 厚さの アクリル板をスリット先端までシリコンゴムで接着し, 電解液 $\left(1 \mathrm{~N} \mathrm{H}_{3} \mathrm{BO}_{3}+0.033 \mathrm{M} \mathrm{KCl}+0.02 \mathrm{M}\right.$ 于才尿素) を注入し， $5 \mathrm{~A} / \mathrm{m}^{2}$ で水素チャージした。座標原点をノ ッチ先端, 板厚中心とし, 負荷方向を $X$, 板厚方向を $Z$ とする. \#10の AE 6-1 センサーと\# 9 の変位センサ 一（PAC，S 9208）を負荷軸と直交する面に設置し AE を検出した。この位置はへき開型破壞による最も大きな 縦波が検出できる位置である.これらのセンサー出力 は, 前節で使用したプリアンプと 2 チャンネルディジタ イザーで離散化データとした。また，8個の PICO セン サー（\#1-8，それらの座標は Fig. 6 の波形に示した） によって縱波を検出し, 音源位置評定とモーメントテン サー解析を行った. PICO センサーの出力は $40 \mathrm{~dB}$ 增幅 した後, 8 チャンネルディジタイザーで離散化データと
したが，離散化条件は同じ（50 ns×1024 points）であ る. 8 チャンネルディジタイザーを改造して，\#1-10の センサーはすべて同期できるようにした。

また，微小破壊発生の前駆過程がレーザ緹波の速度変 化として測れるかを検討するため，レーザ超音波システ ムを用いてノッチ先端から $1 \mathrm{~mm}$ の部分を横切るよう に（Z方向に）縦波を発生・検出した。すなわち，試 験片側面に塗布したシリコンオイルのレーザブレークダ ウン（この場合は mono-pole force で実効立ち上がり時 間は $0.03 \mu \mathrm{s}$ ）によって球面波を発生させ, 震央応答を ヘテロダイン干渉計で測定した。レーザ干涉計は, パル ス YAGレーザと同期させ，その出力は高速ディジタイ ザー（テクトロニクス RTD 720）を用いてサンプリン

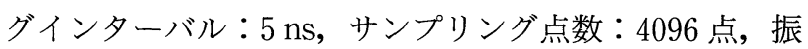
幅分解能： 8 bit でディジタルデータとした。レーザ超 音波では高精度の光軸調整が必要であるため, 小型油圧 負荷装置を試作して $17.64 \mathrm{kN}$ の定負荷をあたえ，負荷 装置全体を 3 軸微動調整用ステージ（自作）に設置して 調整した。ブレークダウンによって発生した弾性波はす べての AEセンサーが検出するので，遅れ破壊による $\mathrm{AE}$ が検出されるようになるとレーザ照射間隔を長く

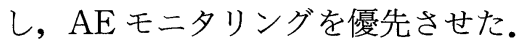

\section{2 実験的応答関数を用いた逆解析による遅れ破壊 のダイナミクス}

遅れ破壞負荷開始 $168.308 \mathrm{ks}$ (46.75 時間) 後に最初 の $\mathrm{AE}$ が検出され, 実験終了（178 ks）までほほ連続的 に 92 個の $\mathrm{AE}$ を検出した. Fig. 6 には, 一例として $\mathrm{AE}$ データカウント(以後 D. C.) 3 の検出波（168.378 ks で検出)を示す. 上段の 8 つの波が PICO センサーに よる検出波で, 縦波のポラリテイーはすべて負でへき開 型破壊を意味している。モーメントテンソル解析9) によ る shear ratio（SR，せん断破壊成分の寄与率で $45 \%$ 以 下はへき開型破壞15)）を調べた結果，12\%でへき開型破 壊であった。この波の音源は，座標 $(X, Y, Z)$ が 
D.C. 3 (168378 s)
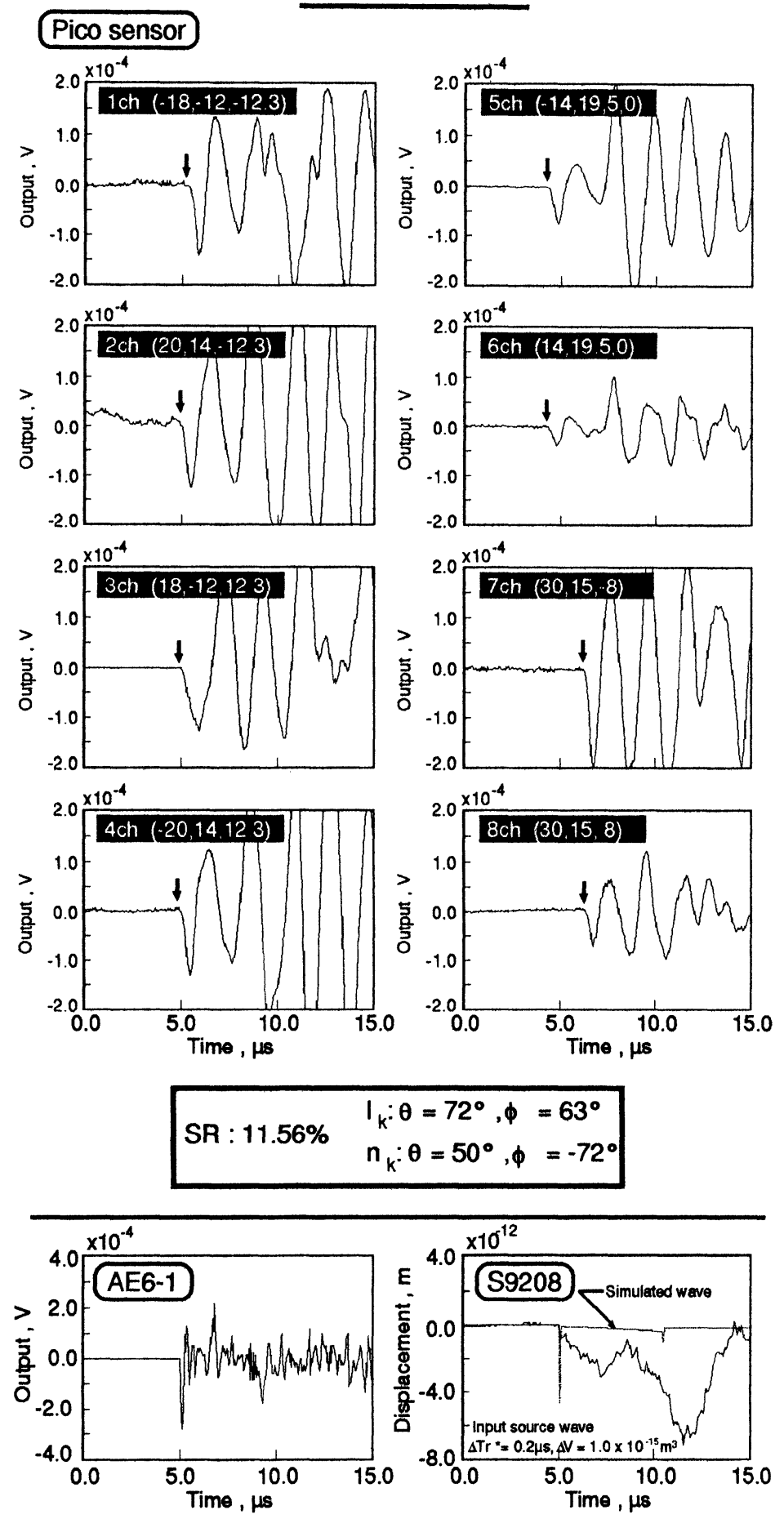

Fig. 6 Waveforms detected by PICO, AE $6-1$ and S 9208 sensors during delayed fracture of SCM 440.

$(0.6,1.0,-7.5) \mathrm{mm}$ で，Fig. 7に示す試験片左側の ノッチ先端から $1 \mathrm{~mm}$ 離れた高静水圧部で発生してい る. 図の左下に示した AE6-1センサーの波形には，5.0 $\mathrm{s}$ に縦波， $9 \mu \mathrm{s}$ に横波が見られる. $7 \mu \mathrm{s}$ に見られるピー クは反射縦波である。一方，右のS 9208 センサー波形 には, $\Delta T r^{*}=0.2 \mu \mathrm{s}$ のへき開破壊に対する計算面外変 位（simulated）も示したが，センサー帯域が狭いため 初動緹波変位が正しく検出されていない. 破壊のダイナ ミクスは，初動縱波について行うので，狭帯域センサー
を使う方法では限界があることを示している。

Fig. 7 には音源位置の経時変化を示す. 最初の $\mathrm{AE}$ 群 は右の図にグループ 1 として示すように, 静水圧場（ノ ッチ先端から約 $1 \mathrm{~mm}$ 程度離れた場所）で発生した後, グループ $2 \rightarrow 3 \rightarrow 4$ の順, すなわち, 反時計周りに+ $Z$ 方向にまわり込むように進展している， $Y=1 \mathrm{~mm}$ の破 線はレーザ縦波の最短伝播経路を示す。微小破壊は縦波 伝播経路を避けるように伝播している。 $\mathrm{AE}$ 源は,グル ープ 1,2, 3,4 に分けたように，かなり広い（離れた）領 
域から発生している。すなわち， 1 個の微小破壊が断続的に成長し ていく過程を捕らえているのでは なく, 色々な場所で発生する微小 破壊の $\mathrm{AE}$ を検出している.

モーメントテンサー解析の結 果，168〜171 ks 間に検出された 48 個の $\mathrm{AE}$ の SR は35\%以下で へき開型割れであるが，172～173 $\mathrm{ks}$ で検出された AEでは SR が 50\%を超えるものもあった。後者 の $\mathrm{AE}$ は, き裂先端の回り込み (グループ 2,3 に対応）に伴って せん断力が大きくなって発生した ものと考えられ，原波形解析から はずした。すなわち，レーザブレ ークダウンはへき開型破壊を模擬 するので, 混合モード破壊に対す る応答関数は求まらないからであ る.

試験終了後もノッチ先端は開口 していなかったため，薄い砥石を 用いて切込みを入れたのち，シリ コンオイルを注入し，ブレークダ ウンを利用して一括応答関数を求 めた. 切込み深さは, Fig. 7 に示

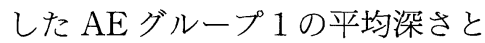
した。縦波変位のシミュレーショ ンでは，レーザ照射位置が $\mathrm{AE}$ 音源位置より 2 $\mathrm{mm}$ 離れても, $3 \%$ 程度変化するのみであるの で，グループ1の中央付近でブレークダウンを起 こさせれば波形シミュレーションには大きな誤差 は与えないと考えられる。

Fig. 8 にはD.C. 5 と 15 の検出波とシミュレー ション波形を示した. 初動縦波の立ち下がり時間 と振幅值が，検出波のそれらと一致するように原 波形を求めた。

D.C. 5 の $\Delta r^{*}$ は $0.1 \mu \mathrm{s}, 15$ のそれは $0.07 \mu \mathrm{s}$ と推定された. Fig. 9 は, 推定したき裂体積 $\Delta V$ と $\Delta T r^{*}$ の関係を示すが， $\Delta T r^{*}$ は 0.07 から $0.25 \mu \mathrm{s}$ である。き裂体積は， $0.5 \times 10^{-15} \mathrm{~m}^{3}$ か ら $7.7 \times 10^{-15} \mathrm{~m}^{3}$ の範囲に推定された。同図に は，変位センサーを用いた前報 ${ }^{9)}$ の実験で解析さ れた領域をシャドウで示すが，これまでの実験で は比較的大きなき裂，すなわち体積 $2 \times 10^{-15} \mathrm{~m}^{3}$ から $10^{-14} \mathrm{~m}^{3}$ （き裂大きさでは 40〜150 $\mu \mathrm{m}$ ）を 検出していた。なお，前報では $\Delta T r$ を使用して いたので $\Delta T r^{*} に$ 直して表示した。微小割れはノ ッチ先端から離れた場所で分離して発生している ため， $b_{x}$ が計算出来ず割れ大きさ $A$ を推定する ことが難しいが，前報9) の $b_{x}=2 \mu \mathrm{m}$ を使用して 計算すると, 多くの割れ大きさは $10 \mu \mathrm{m}$ 以下で ある.この大きさは旧オーステナイト粒径よりも 小さく，これまで検出できなった微小な破壊を検出でき たといえる。なお，図中に示した 2 本の直線は， $b_{x}=2$ $\mu \mathrm{m}$ として計算される円状割れ直径から推定した破壊速

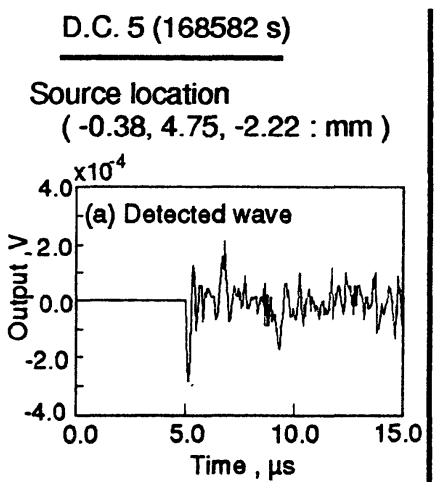

D.C. 15 (169396 s)

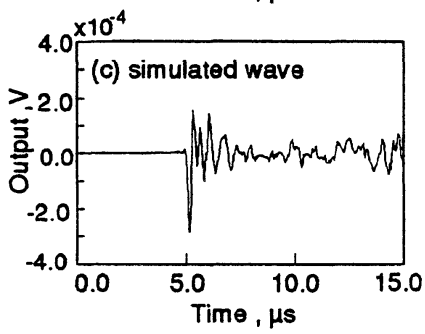

Source location
$(-0.65,5.18,0.86: \mathrm{mm})$
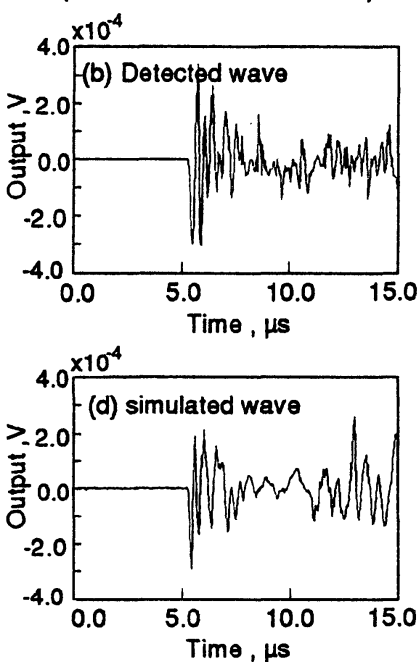

Source parameter
$\Delta \mathrm{Tr}^{*}=0.1 \mu \mathrm{s}$
$\Delta V=1.14 \times 10^{-15} \mathrm{~m}^{3}$

- Source parame $\Delta \mathrm{Tr}^{*}=0.07 \mu \mathrm{s}$ $\Delta V=1.20 \times 10^{-15} \mathrm{~m}^{3}$

Fig. 8 Comparison of detected and simulated waveform during delayed fracture of SCM 440.

度で， $180 \mathrm{~m} / \mathrm{s}$ から $550 \mathrm{~m} / \mathrm{s}$ の範囲にある．前報の結果 が 2 本の直線（速度 182 から $558 \mathrm{~m} / \mathrm{s}$ ）の範囲に入って いることは，小さな割れの生成速度も大きな割れのそれ 


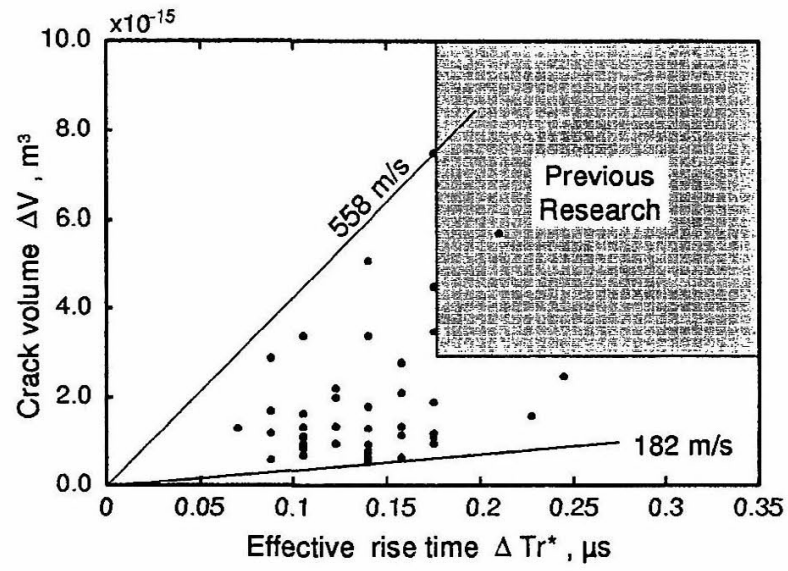

Fig. 9 Crack volume and effective source rise time during delayed facture.

もほぼ可じ範囲にあることを示している。

\section{3 レーザ縦波速度の経時变化による遅れ破壊の前 駆過程}

Fig. 10 にはレーザ干渉計で検出した震央応答の経時 変化を示す. 時間 $0 \mathrm{ks}$ は Y AGレーザ発信時間と一致 しており, 検出波形はインパルス力に対する解析的震央 変位と良く一致している． $\mathrm{P}_{3}$ は対面での反射縱波， $\mathrm{S}$ と $\mathrm{P}_{3}$ の間にみられる波はノッチ先端で反射された縦波

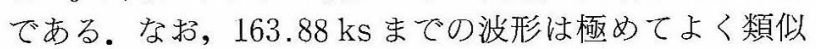
し time-of-flight 法（伝播距離を初動緹波のゼロクロス 到達時間で除す方法) で求めた速度は $5975 \pm 11 \mathrm{~m} / \mathrm{s}$ で，速度誤差は $0.2 \%$ 以下である。最初の $\mathrm{AE}$ は 168.3 $\mathrm{ks}$ で検出されたが，その $2.8 \mathrm{ks}$ 前すなわち時間 165.6 ks には初動縦波の到達時間が $0.07 \mu \mathrm{s}$ （ディジタルデー タでは 17 ポイント) 遅れ, 振幅は減少し, 分散性の波 形（長時間側に尾を引く波形）に変化している.また， $\mathrm{S}$ と $\mathrm{P}_{3}$ の間に新しい波が見られ， $\mathrm{P}_{3}$ 波が不明になって いる.

Fig. 11(a)に示したように, 縦波速度は $\mathrm{AE}$ 発生の直 前に $100 \mathrm{~m} / \mathrm{s}$ 低下し, $\mathrm{AE}$ 発生中にも低い速度を示し t.

この試験片では，Fig. 7 に示したように，き裂はレー ザ縦波伝播経路を避けるように伝播したため, 最初の $\mathrm{AE}$ が検出されるわずか $2.8 \mathrm{ks}$ 前で速度変化が見られ たが，き裂先端が直線的に進展した別の CT 試験片（厚 さ $13.8 \mathrm{~mm}$ ) では, Fig. 11(b)に示すように最初の $\mathrm{AE}$ が検出される $25.3 \mathrm{ks}$ (7.02 時間) も前に速度が減少し た。

この場合も, 速度の低下は $100 \mathrm{~m} / \mathrm{s}$ 程度であったが, $\mathrm{AE}$ が検出されなくなると（音源がグループをつくって 移動する場合に観察される $\left.{ }^{16)}\right)$, 速度は $5950 \mathrm{~m} / \mathrm{s}$ まで回 復する，速度の可逆変化が，水素を吸蔵しつつある試験 片のノッチ先端で起こるのかなど末解明な点も多い。

レーザ縦波の速度変化が, 材料のどのような構造変化 によるものかは明らかになっていない，縦波速度は $\sqrt{\frac{(1-\nu)}{E \rho(1+\nu)(1-2 \nu)}}$ で与えられるので, 空孔による散 乱がなければ, ポアソン比 $\nu$, ヤング率 $E$, 密度 $\rho$ に
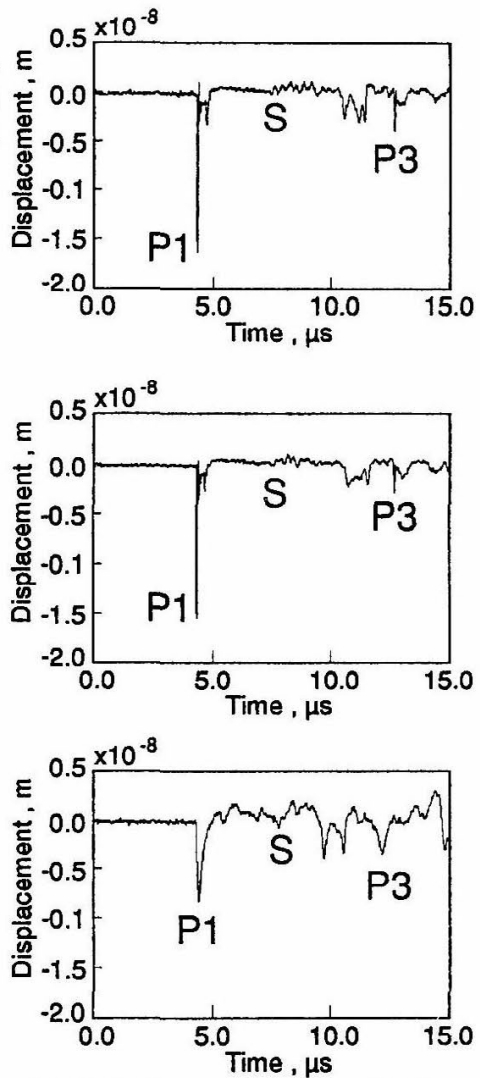

\section{Detection of the first AE at 168.3ks.}

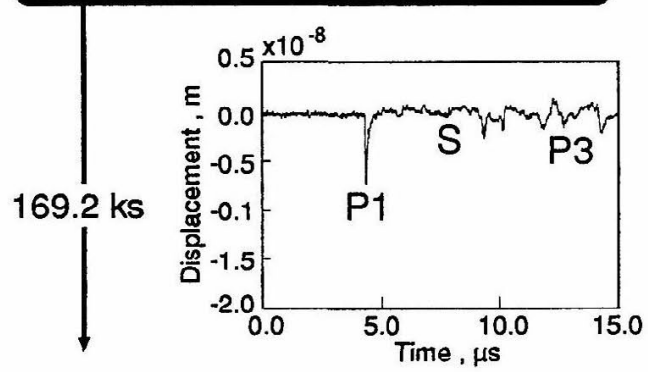

Fig. 10 Change of pulse laser excited longitudinal wave with test time during hydrogen charging to loaded SCM 440.

よって変化する，水素吸蔵によって格子脆化が起こるな

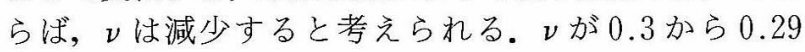
に変化すると, $\sqrt{\frac{(1-\nu)}{(1+\nu)(1-2 \nu)}}$ は $1.9 \%$ 減少し, 113 $\mathrm{m} / \mathrm{s}$ の縦波速度の低下をもたらす。この仮定は測定さ れた速度低下を説明できるが, 水素吸蔵によって密度も 低下し， $E$ も変化する（増大するか減少するかは不明） であろうから，ポアソン比だけで論じられるものでもな い. 水素吸蔵による 3 つの物性 $(E, \rho, \nu)$ 変化を独立 して $2 \%$ 程度の精度で測定することはひずみゲージ法で はほとんど不可能である。一方，払散性水素汇よって発 生したボイドに起因しているなら，前駆過程を非破壞的 に捕光られる可能性がある. しかし，高静水圧で生成し た水素ボイドがぞの上うな過程を経て, $\mathrm{AE}$ 発牛を伴う へき開型高速割れに至るのか，不明な点は多い. 今回用 いたレーザシステムの周波数は $20 \mathrm{MHz}$ で縦波の波長 は $300 \mu \mathrm{m}$ 程度である. 今後, $40 \mathrm{MHz}$ 帯域レーザ超音 

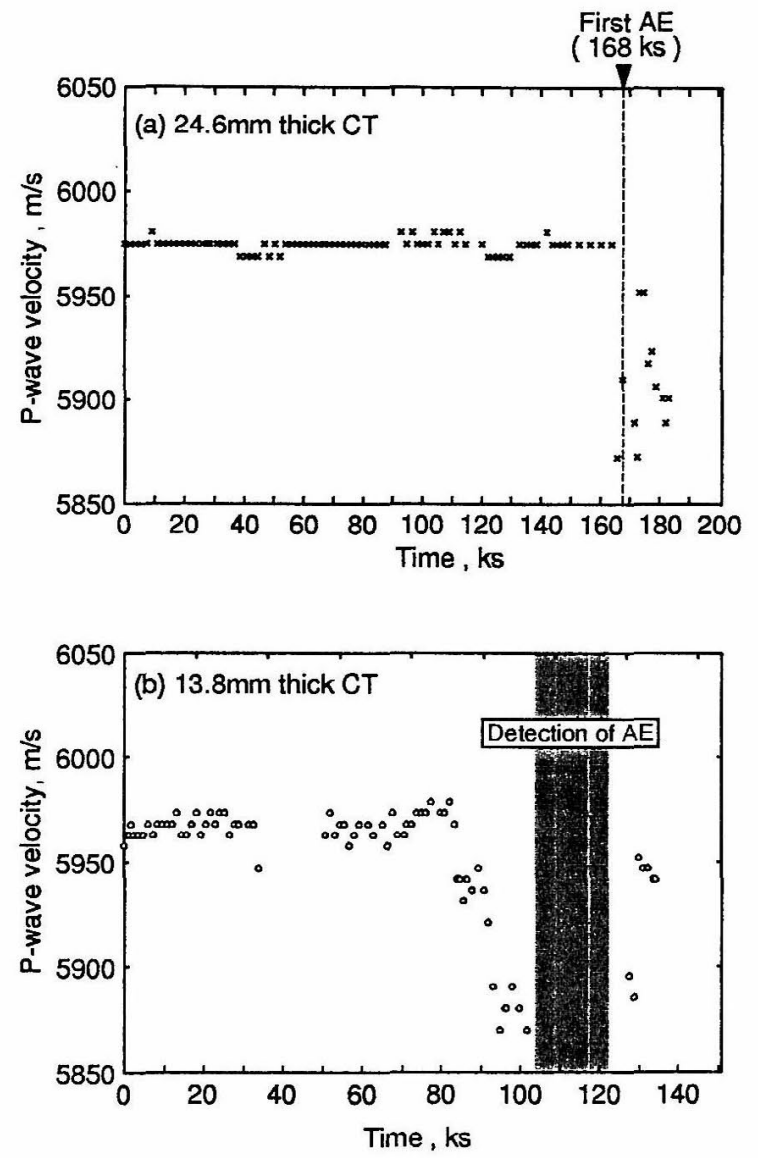

Fig. 11 Change of laser $P$-wave velocity in high hydrostatic stress field of $24.5 \mathrm{~mm}$ thick (a) and $13.83 \mathrm{~mm}$ thick(b) CT specimens.

波システムを用いて，水素を吸蔵する鋼の縦波速度と減 衰について詳細に検討し, いわゆる前駆過程のメカ二ズ ムを明らかにして行く予定である。

\section{4. 結論}

遅れ破壊のダイナミクスと前駆過程を調べる目的で， $7 \mathrm{MHz}$ 帯域の $\mathrm{AE}$ 原波形解析システムと $20 \mathrm{MHz} レ$ ザ超音波システムを開発した。得られた結果は以下のよ うに要約される。

(1) 多重共振型 $\mathrm{AE}$ センサーを用いる $7 \mathrm{MHz}$ 帯域 ディジタル AE 装置を構築した。隙間内に充填したシリ コンオイルのパルス・レーザブレークダウンで発信した 縦波をレーザ干渉計で計測した結果，バーガースベクト ルがき裂壁法線方向のへき開型破壊（人工破壊源）を模 擬できることがわかった。人工破壊源の体積はレーザエ ネルギーによって変化するが，生成時間はエネルギーに

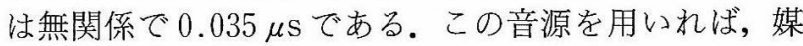
体と $\mathrm{AE}$ 測定装置を一括した $10 \mathrm{MHz}$ 帯域の応答関数 が求まり，高速破壊の $\mathrm{AE}$ 原波形解析を可能に一る。

（2）低合金鋼 CT 試験片の遅れ破壊中に検出される $\mathrm{AE}$ の音源位置詮定とモーメントテンソル解析, 実験的 応答関数を用いる原波形解析を行った．最初の微小破壊 は)ッチ先端の高静水圧応力場で発生した.モーメント
テンソル解析でへき開型破壊と同定された微小破壊につ いて，波形シミュレーションを行った結果，体積 $7.7 \times$ $10^{-15} \mathrm{~m}^{3}$ 以下の微小破壊が $0.07 \sim 0.2 \mu \mathrm{s}$ で発生してい ることが分かった。広带域 AEシステムで解析できた破 壊面積は，市販変位センサーで解析できたそれの $1 / 2$ 程 度であった。すなわち，10 $\mu \mathrm{m}$ の大きさの高速破壊の 検出を可能にした。

（3） $20 \mathrm{MHz}$ 帯域レーザ超音波システムを用いて， ノッチ先端の高静水圧場を横切るように伝播させた縦波 速度 $(5975 \mathrm{~m} / \mathrm{s})$ は，最初の $\mathrm{AE}$ が検出される $2.8 \mathrm{ks}$ 前に $100 \mathrm{~m} / \mathrm{s}$ 低下した。一方，縱波伝播経路を広範团 に横切るように割れが発生した別種試験片では，最初の $\mathrm{AE}$ 発生 $25.3 \mathrm{ks}$ 前に縦波速度が $100 \mathrm{~m} / \mathrm{s}$ 減少した. 速 度減少の原因は必ずしも明らかではないが，遅れ破壊を おこす低合金鋼に固有の現象で，遅れ破壊の前駆過程を 調べられる可能性がある。

\section{謝 辞}

本研究は，文部省科学研究費（課題番号 11450278）, 熊谷研究財団扔よび新日本製鐵(株) からの研究助成金 によってなされた。また，多重共振型センサーAE 6-1 は山形大学 富川義朗教授に提供していただいた。ここ に記して謝意を表する。試験装置の作製に協力した往年 の大学院生, 小川真吾, 田村宙治, 元助手鈴木裕晶 (現, 千代田化工建設(株), 長英雄 (現, 東北大学助 手)，(有) 新和精工社長小川豊氏心感謝する。

\section{参 考 文 献}

1) H. N. G, Wadly, C. B. Scruby and G. Shimpson : Acta Metallurgica, 29, 399 (1980).

2) T. Ohira and Y. Pao: Metallurgical Trans., 17 A, 843 (1986).

3) T. Ohira and Y. Pao: Metallurgical Trans., 20, 1105 (1989).

4）岸 輝雄, 大野一生, 栗林一彦: 非破壊検査, 30 , 911 (1981).

5 ) 大平貴規，岸 輝雄：日本金属学会誌，46，518 (1982).

6）大津政康：材料，32，577（1983）。

7) M. Ohtsu: Materials Evaluation, 45, 1070 (1987).

8) M. Ohtsu and K. Ono: J. Acoustic Emission, 3, 27 (1984).

9）竹本 誠, 林 泰久, 竹本幹男 (M. Takemoto, Y Hayashi and M. Takemoto): 材料と環境 [Zairyo-toKankyo (Corros. Eng.)], 43，637 (1994), おるび非 破噮検查, 43, 637 (1994)。

10) H. Suzuki, M. Takemoto and K. Ono:J. Acoustic Emission, 14, 35 (1996)

11）田村宙治, 竹本幹男：鉄と鋼，83，532（1997）.

12）田村宙治，竹本幹男 (O. Tamura and M. Takemoto)： 材料と環境 [Zairyo-to-Kankyo, (Corros.Eng.)]，46， 256 (1997).

13）田村宙治, 竹本幹男：鉄と鋼，83，255(1998).

14）富川義朗, 柳橋実, 㩊葉秀弘: 非破壊検查, 37 , 196 (1988).

15) N. N. Hsu, J. A. Simons and S. C. Scruby : Mat. Eval., 45, 100 (1977).

16) Y. Hayashi, M. Takemoto and M. Takemoto: $C O R$ ROSION '94, Paper No. 220 (1994).

(Manuscript received September 3, 1999 in final form November 16,1999 ) 